\title{
ANTIFUNGAL PROPERTIES OF CLOVE OIL (EUGENIA CARYOPHYLATA) IN SUGAR SOLUTION
}

\author{
Lidia Núñez ${ }^{1 *}$; Miguel D’Aquino'; Jorge Chirife ${ }^{2}$ \\ ${ }^{1}$ Cátedra de Sanidad e Higiene, Facultad de Farmacia y Bioquímica, Universidad de Buenos Aires, Buenos Aires, Argentina. \\ ${ }^{2}$ Departamento de Industrias, Facultad de Ciencias Exactas y Naturales, Universidad de Buenos Aires, Buenos Aires, Argentina
}

Submitted: April 07, 2000; Returned to authors for corrections: September 14, 2000; Approved: May 25, 2001

\begin{abstract}
The effect of temperature, concentration and contact time on the fungicidal effect of clove oleoresin dispersed in a concentrated sugar solution at 21 and $37^{\circ} \mathrm{C}$, and clove oleoresin at 0.2 to $0.8 \%(\mathrm{v} / \mathrm{v})$ was studied. The test microorganisms were Candida albicans, Penicillium citrinum, Aspergillus niger and Trichophyton mentagrophytes. The fungicidal effect was enhanced at $37^{\circ} \mathrm{C}$; at this temperature short contact times (e.g. $1 \mathrm{~min}$.) were enough to eliminate a microbial inoculum of $10^{6} \mathrm{c}$.f.u. $/ \mathrm{ml}$ of C. albicans. Although clove oleoresin caused important lethal effect, $P$. citrinum and A. niger were more resistant. After 60 minutes, clove oleoresin dispersed $(0.4 \% \mathrm{v} / \mathrm{v})$ in concentrated sugar solution caused a $99.6 \%$ reduction of the initial population $\left(10^{6}\right.$ c.f.u. $\left./ \mathrm{ml}\right)$ of Trichophyton mentagrophytes. The fungicidal activity of clove-sugar on C. albicans, after 2 min contact, was similar to that presented by disinfectants commonly used in hospitals, such as povidone-iodine and chloroxylenol.
\end{abstract}

Key words: clove oil, fungicide, disinfectant, sugar

\section{INTRODUCTION}

In the past few years several papers have been published on the use of sugar (sucrose) for the treatment of infected wounds. These paper comprised clinical studies $(10,11,14,17,20)$ and "in vitro" experiments on the antimicrobial activity of sucrose against bacteria pathogenic for humans $(1,4,18)$. Although it has been well established that pathogenic bacteria cannot grow in sugar solutions with low water activity $\left(\mathrm{a}_{\mathrm{w}}\right)$, the lethal effect of sugar on certain pathogens is slow and clinical situations may exist where the killing of these microorganisms in a short time is desirable. Previous attempts to increase the efficacy of sugar teraphy were reported by Briozzo et al. (3) and Chirife et al. (6), who studied the "in vitro" antibacterial effect of clove oleoresin dispersed in a concentrated (saturated ) sugar solution $\left(\mathrm{a}_{\mathrm{w}}=0.83\right)$. They reported that this system had a marked bactericidal effect comparable to that of various disinfectants which are commonly used in hospitals. They determined that clove oleoresin was reponsible for the bactericidal action.
Although the water activity of a saturated sugar solution is low enough $\left(a_{w}=0.83\right)$ to inhibit the growth of pathogenic bacteria, some molds may be able to grow since their minimal water activity for growth is below 0.83 (19). The present work studied the effect of the addition of clove oleoresin (Eugenia caryophyllata) on the survival of several molds in saturated sugar solutions.

\section{MATERIALS AND METHODS}

\section{Microorganisms}

Candida albicans MN 84031, Aspergillus niger ATCC 16404, Penicillium citrinum F-300, and Trichophyton mentagrophytes ATCC 94795 were used in this study. The microorganisms were grown on malt extract agar (Merck, Darmstadt, Germany), except T. mentagrophytes, which was cultured in Sabouraud - glucose $2 \%$ agar (Merck, Darmstadt, Germany). Candida albicans was incubated for $24 \mathrm{~h}$. at $37^{\circ} \mathrm{C}$ and the other three strains (A. niger, $P$. citrinum and T. mentagrophytes) were incubated for 15 days at

\footnotetext{
* Corresponding author. Mailing Address: Cátredra de Sanidad e Higiene, Facultad de Farmacia y Bioquímica, Universidad de Buenos Aires, Junin 956 (1113) Buenos Aires, Argentina. Tel.: (+5411) 964-8258, Fax (+5411) 508-4635. E-mail: lidian@ huemul.ffyb.uba.ar
} 
$25^{\circ} \mathrm{C}$. After growth, C. albicans cells and spores of the fungal strains were suspended in saline solution with $0.05 \%$ Tween 80 . The suspensions were filtered with sterilized gauze and adjusted to a concentration of approximately $10^{8} \mathrm{cell} / \mathrm{ml}$.

\section{Test solution for antimicrobial activity}

The test solution was prepared with refined granulated cane sugar $(63 \% \mathrm{w} / \mathrm{w})$, acquired from a retail store, to which variable amounts $(0.2-0.8 \% \mathrm{v} / \mathrm{v})$ of food-grade clove oleoresin $(\mathrm{CO})$, provided by Fritzsche S.A.I.C.A. (Buenos Aires, Argentina), was added. The CO was dissolved in PEG-400 (50\% v/v) (3).

The fungicidal effect of CO-sugar was compared with disinfectants commonly used in hospitals, such as povidoneiodine (1\% of free iodine) at $0.5 \%$ and soapy solution of chloroxylenol $(0.3 \%)$.

\section{Fungicidal effect}

Trials to determine the fungicidal effect were made following a previously described procedure $(3,5)$. Briefly, $9.9 \mathrm{ml}$ of test solution were placed in a water bath at $21^{\circ} \mathrm{C}$ or $37^{\circ} \mathrm{C}$, and $0.1 \mathrm{ml}$ of inocula was added. Samples were withdrawn periodically, diluted with the appropriate inactivator and submitted to microbial counts as described below. Plates were incubated at $25^{\circ} \mathrm{C}$ for $48 \mathrm{~h}$ for $C$. albicans and 5 days for the other microorganisms.

$\mathrm{CO}$ and p-cloroxilenol were inactivated using 3\% Tween 80 and povidone-iodine with $0.1 \%$ sodium thiosulfate; the effectiveness of inactivation was experimentally evaluated following a previously described procedure (5).

All neutralized dilutions were surface-spread in petri dishes with malt extract agar (Merck, Darmstadt, Germany), except $T$. mentagrophytes, which was plated on Sabouraud - glucose $2 \%$ agar (Merck, Darmstadt, Germany).

\section{Control Tests}

The following set of controls were performed: (a) to determine whether or not sugar and PEG-400 possess antimicrobial activity; and (b) to determine whether a vehicle other than the sugar solution (distilled water) has influence on the antimicrobial activity.

\section{(a) Antimicrobial activity of sugar and PEG- 400}

Candida albicans or A. niger $(0.1 \mathrm{ml})$ were added to $9.9 \mathrm{ml}$ of sugar solution and to $9.9 \mathrm{ml}$ of sugar solution containing $0.04 \mathrm{ml}$ of PEG-400. The suspensions were thoroughly mixed and maintained at $21^{\circ} \mathrm{C}$. After $2 \mathrm{~min}$ for the sugar solution and $10 \mathrm{~min}$ for the sugar solution with PEG-400, a sample was withdrawn and submitted to microbial count.

\section{(b) Effect of a vehicle other than sugar solution}

Candida albicans or A. niger $(0.1 \mathrm{ml})$ were added to $9.9 \mathrm{ml}$ of distilled water and to $9.9 \mathrm{ml}$ of sugar solution containing $0.4 \%$ of clove oil. The suspensions were mixed and samples were withdrawn after 2 or $10 \mathrm{~min}$ at $21^{\circ} \mathrm{C}$ and counted.

\section{RESULTS AND DISCUSSION}

As we described in a previous study (4), clove oil caused rapid killing of $C$. albicans. This was confirmed in this study. Sugar solution or sugar solution with PEG-400 or concentrated sugar solution alone did not have the same lethal effect on microorganisms $(4,18)$.

Similar antifungal properties of $\mathrm{CO}$ were observed both in distilled water and sugar solution (3). Nevertheless, the concentrated sugar solution provided a good vehicle in that a relatively more stable dispersion of the oil was easily obtained; this was not the case with distilled water since oil droplets formed soon after oil was dispersed.

Fig. 1 shows the effect of temperature $\left(21^{\circ} \mathrm{C}\right.$ or $\left.37^{\circ} \mathrm{C}\right)$ and concentration of clove oleoresin $(0.2$ or $0.4 \% \mathrm{v} / \mathrm{v})$ dispersed in the concentrated sugar solution on the survival of Candida albicans cells. Clove oleoresin had a fast killing effect on yeast cells and the lethal effect was higher at $37^{\circ} \mathrm{C}$ than at $21^{\circ} \mathrm{C}$. The increase of concentration of $\mathrm{CO}$ from 0.2 to $0.4 \%$ produced a significant increase in the lethal action. At $37^{\circ} \mathrm{C}$ and $0.4 \% \mathrm{CO}$, a contact time of $1 \mathrm{~min}$ reduced drastically the inoculum from about $10^{7}$ c.f.u. $/ \mathrm{ml}$ to 20 c.f.u. $/ \mathrm{ml}$. At $21^{\circ} \mathrm{C}$ and $0.2 \%$ a biphasic behavior was observed instead of a simple logarithmic straight line. This result can attributed to phenotypic and / or genotypic heterogeneity (8).

Figs. 2 and 3 show the effects of clove oleoresin concentration $(0.4$ and $0.8 \% \mathrm{v} / \mathrm{v})$ and temperature $\left(21^{\circ} \mathrm{C}\right.$ and $\left.37^{\circ} \mathrm{C}\right)$ on the survival of Aspergillus niger and Penicillium citrinum. The initial concentrations of inoculum in Fig. 2 were not the same because they represented different samples. The fungicidal effect of $\mathrm{CO}$ on molds was less evident than on C. albicans, and A. niger was much more resistant than $P$. citrinum. None of the survival curves presented a simple logarithmic straight line. Increase of temperature from $21^{\circ} \mathrm{C}$ to $37^{\circ} \mathrm{C}$ improved the effectiveness of $\mathrm{CO}$ towards both molds. Chirife et al. (5) also related increased bactericidal effect of

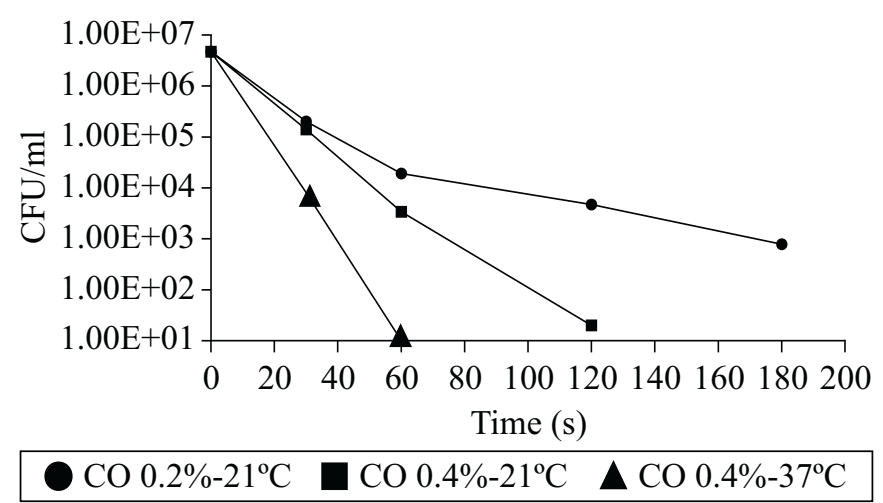

Figure 1. Effect of clove oleorresin (CO) dispersed in a concentrated sugar solution on Candida albicans at $21^{\circ} \mathrm{C}$ and $37^{\circ} \mathrm{C}$. 


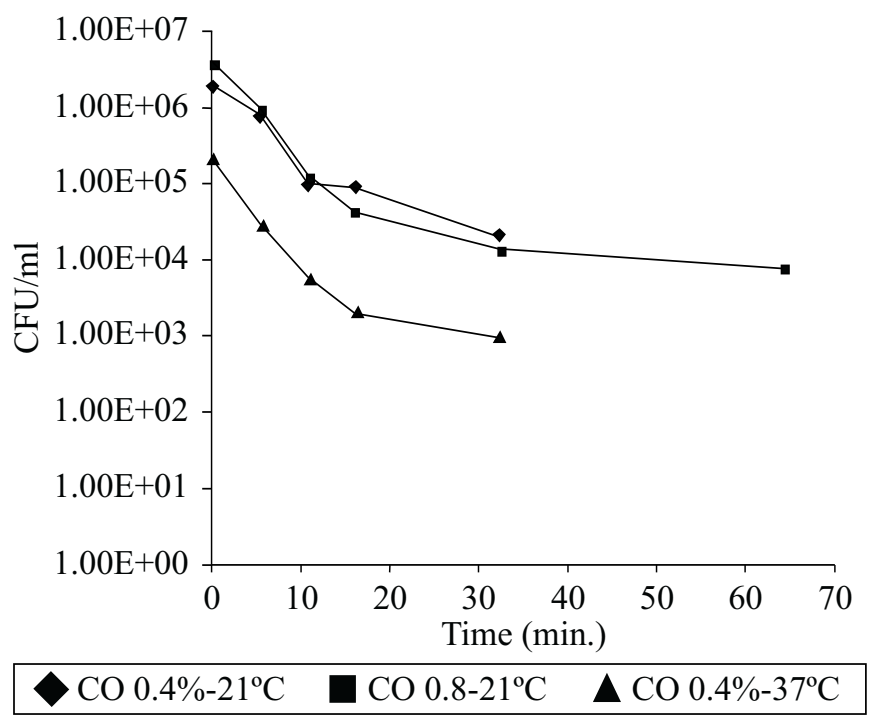

Figure 2. Effect of clove oleoresin (CO) dispersed in a concentrated sugar solution on Aspergillus niger at $21^{\circ} \mathrm{C}$ or $37^{\circ} \mathrm{C}$.

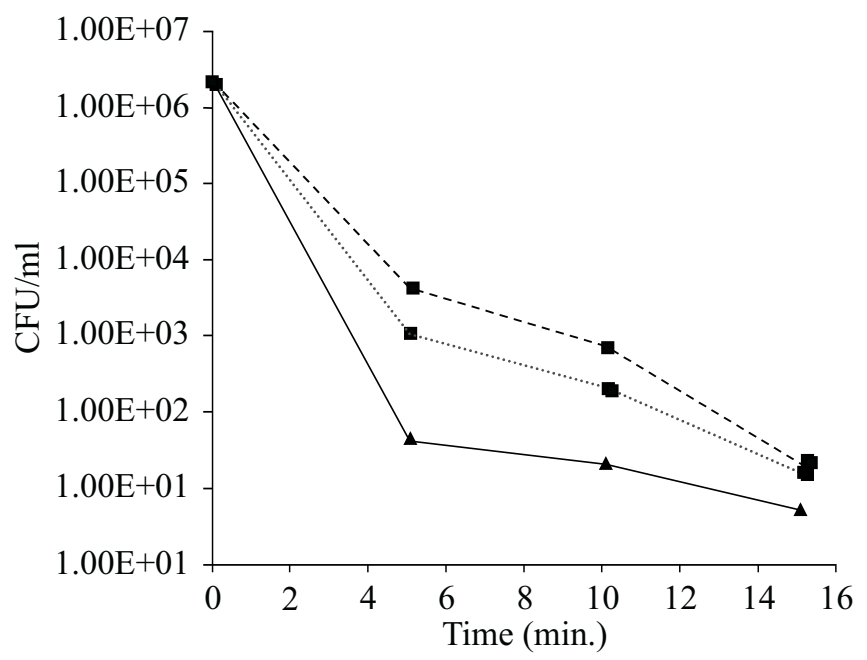

$-\cdots \mathrm{CO} 0.4 \%-21^{\circ} \mathrm{C} \cdots \mathrm{CO} 0.8 \%-21^{\circ} \mathrm{C}-\mathrm{CO} 0.4 \%-37^{\circ} \mathrm{C}$

Figure 3. Effect of clove oleorresin $(\mathrm{CO})$ dispersed in a concentrated sugar solution on Penicillium citrinum at $21^{\circ} \mathrm{C}$ or $37^{\circ} \mathrm{C}$.

CO against Staphylococcus aureus, Escherichia coli and Pseudomonas aeruginosa when the temperature was raised from $21^{\circ} \mathrm{C}$ to $37^{\circ} \mathrm{C}$. However, concentration had minor effect on the survival curves of A. niger and P. citrinum in the range studied (0.4 to $0.8 \%)$.

Despite the higher resistance of molds, clove oleoresin performed satisfactorily in disinfection since $99 \%$ (A. niger) and 99.99\% (P. citrinum) of the exposed population were destroyed within 10 and 5 min contact time, respectively.
Table 1 compares the lethal effect of clove oleoresin and some disinfectants commonly used in hospitals, like povidone-iodine and cloroxylenol, on C. albicans. After $2 \mathrm{~min}$ at $21^{\circ} \mathrm{C}, \mathrm{CO}$ presented the same "in vitro" killing effect as the disinfectants. However, for very short contact times (e.g. $1 \mathrm{~min}$.), the later were more effective.

Fig. 4 shows the effect of $\mathrm{CO}$ dispersed in concentrated sugar solution on the survival curve of Trichopyton mentagrophytes NC 94797 . After $60 \mathrm{~min}$, a destruction of $99.6 \%$ of the $10^{6}$ c.f.u. $/ \mathrm{ml}$ inoculum was observed.

Formerly it was assumed that the fungicidal action was due to clove oleoresin and not to the concentrated sugar solution, which was used mainly as a vehicle for the oleoresin (3). It is well known that concentrated sugar solution has a fungistatic rather than a fungicidal action (18) and this effect is usually explained by the decrease of water activity. Taking into account that the water activity of the sugar solution is 0.83 (4) and the minimal $\mathrm{a}_{\mathrm{w}}$ for growth of $A$. niger and $P$. citrinum are 0.77 and 0.80 respectively

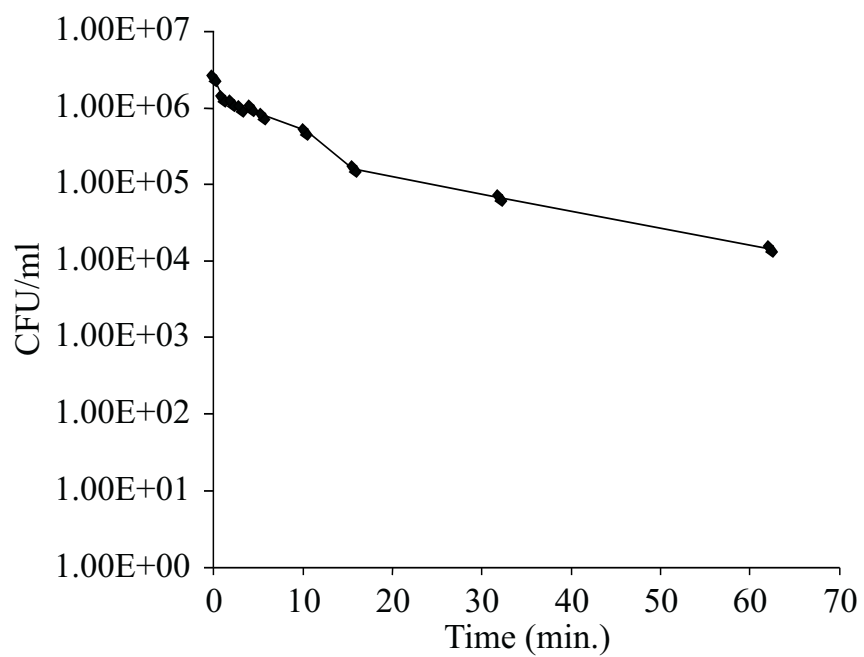

Figure 4. Effect of clove oleoresin (CO) dispersed in a concentrated sugar solution on Trichophyton mentagropytes at $21^{\circ} \mathrm{C}$.

Table 1. Effect of clove oleorresin $(0.4 \% \mathrm{v} / \mathrm{v})$ dispersed in concentrated sugar solution and disinfectants commonly used in hospitals (povidone-iodine and chloroxylenol) in Candida albicans.

\begin{tabular}{cccc}
\hline \multicolumn{4}{c}{ Survivors, \% } \\
\hline $\begin{array}{c}\text { Time of } \\
\text { contact }(\mathrm{sec})\end{array}$ & $\begin{array}{c}\text { Clove } \\
(0.4 \%)\end{array}$ & $\begin{array}{c}\text { Povidone } \\
(0.5 \%)\end{array}$ & $\begin{array}{c}\text { Chloroxylenol } \\
(0.3 \%)\end{array}$ \\
\hline 0 & 100 & 100 & 100 \\
30 & 5 & 0.01 & 0.1 \\
60 & 0.1 & 0.005 & 0.05 \\
120 & 0.001 & 0.001 & 0.005 \\
180 & $<0.001$ & $<0.001$ & 0.001 \\
\hline
\end{tabular}


(16), a lower $\mathrm{a}_{\mathrm{w}}$ should play only a minor role in the fast fungicidal action attributed to clove oleoresin. Selwyn and Durodie (18) studied the behavior of $C$. albicans in a saturated sugar solution, and reported growth inhibition followed by a slow reduction in number of cells as a function of contact time. A contact time of 12 hours was required to reduce the inoculum size by one log cycle. This contrasts with the very fast fungicidal action observed in present work for the clove oleorresin-sugar mixture.

Spices, herbs and their essential oils, commonly used as food seasonings, present well known antimicrobial activity $(9,12,15)$. Benjilali et al. (2) reported the antifungal properties of essential oil of various plants (thyme, rosemary, mugwort and various species of mint) which were tested against 39 mold strains. Mahmoud (13) tested the antifungal effect of some essential oils on growth of molds and aflatoxin production. Clove was among the substances with antifungal activity. Connor and Beuchat (7) observed that 32 different essential oils from plants, allspice, cinnamon, clove, garlic, oregano, savoury, and thyme were particularly inhibitory to selected food spoilage and industrial yeasts.

Results of the present work demonstrated that the association of clove oleoresin with concentrated sugar has a strong fungicidal effect. Further studies are required to demonstrate the usefulness of this association for topical treatment of mycotic infections. Nevertheless, absence of any harmful effect on human tissues should be demonstrated before clove oleoresin is recommended for clinical application. No adverse effect to normal wound healing or any other unfavorable effect should also be demonstrated.

\section{RESUMO}

\section{Propriedades antifúngicas do óleo de cravo (Eugenia caryophyllata) numa solução de açúcar}

No estudo avaliou-se o efeito da temperatura, concentração e tempo de contato na atividade antifúngica do óleo essencial do cravo disperso em solução concentrada de açúcar. Os ensaios foram feitos a $21^{\circ} \mathrm{C}$ e a $37^{\circ} \mathrm{C}$, utilizando suspensão de óleo essencial de 0.2 a $0.8 \%$ v/v. Os microorganismos utilizados foram Candida albicans, Penicillium citrinum, Aspergillus niger e Trichophyton mentagrophytes. A melhor atividade fungicida ocorreu a $37^{\circ} \mathrm{C}$, onde um minuto de contato foi suficiente para matar uma população de $10^{6}$ u.f.c./ml de Candida albicans. Não obstante, $P$. citrinum, A. niger, T. mentagrophytes foram mais resistentes, embora uma importante ação letal da essência tenha sido observada. Em 60 minutos, o óleo essencial de cravo ( $0,4 \%$ v.v.) em solução concentrada de açúcar reduziu em $99,6 \%$ um inóculo de $10^{6}$ u.f.c./ $\mathrm{ml}$ de T. mentagrophytes. O efeito letal do óleo essencial de cravo sobre $C$. albicans, após 2 minutos de contato, foi semelhante ao de desinfectantes comumente usados em hospitais, como povidona-iodo e cloroxilenol.

Palavras-chave: cravo, fungicida, desinfectante, açúcar

\section{REFERENCES}

1. Ambrose, U.; Middleton, K.; Seal, D. In vitro studies of water activity and bacterial growth inhibition of sucrose- polyethylene glycol- 400hydrogen peroxide and xylose-polyethylene glycol-400-hydrogen peroxide past used to treat infected wounds. Antim. Agents and Chemoth., 35:1799-1803, 1991

2. Benjilali, B.; Tantaoui-Elaraki, A.; Ayadi, A.; Ihlal, M. Method to study antimicrobial effects of essential oils: application to the antifungal activity of six Moroccan essences. J. Food Protec., 47: 748-752, 1984.

3. Briozzo, J.; Nuñez, L.; Chirife, J.; Herszage, L.; D’Aquino, M. Antimicrobial activity of clove oil dispersed in a concentrated sugar solution. J. Appl. Bacteriol., 66: 69-77, 1988.

4. Chirife, J.; Herszage, L.; Joseph, A.; Kohn, E.S. In vitro study of bacterial growth inhibition in concentrated sugar solutions: microbiological basis for the use of sugar in the treatment of infected wound. Antim. Agents Chemoth., 23: 766-773, 1983.

5. Chirife, J.; Nuñez, L.; Ballesteros, S.A.; Bozzini, J.P.; Herszage, L.; D’Aquino, M. Estudios sobre la acción bactericida del aceite de clavo de olor dispersado en una solución de azúcar. Rev. Arg. Microbiol., 24: 32-39, 1992.

6. Chirife, J.; Herszage, L.; Joseph, A.; Kohn, E.S. Effect of potassium sorbate and $\mathrm{pH}$ on the survival of Stapylococcus aureus in saturated sugar solution. Rev. Arg. Microbiol., 25:80-87,1993.

7. Conner, D.E.; Beuchat, L. Sensitivity of heat-stressed yeast to essential oils of plants. Appl. Environm. Microbiol., 47: 229-233, 1984.

8. D' Aquino, M.; Santini, P.; Muzio, H. Action of halogenated compounds on Aspergillus conidiospores. J. Food Protec., 49: 537-540, 1986.

9. Deans, S.G.; Ritchie, G. Antibacterial properties of plant essential oils. Int. J. Food Microbiol., 5: 165-180, 1987

10. Gordon, H.; Middleton, K.; Seal, D.; Sullens, K. Sugar and wound healing. The Lancet, ii:663-664, 1985.

11. Herszage, L.; Montenegro, J.R.; Joseph, A.L. Tratamiento de las heridas supuradas con azúcar granulado comercial. Boletín de Trabajos de la Sociedad Argentina de Cirugía, 41:315-330, 1980.

12. Hili, P.; Evans, C.S.; Veness, R.G. Antimicrobial action of essential oils: the effect of dimethylsulphoxide on the activity of cinnamon oil. Lett. Appl. Microbiol., 24:269-275, 1997.

13. Mahoud, L.E. Antifungal action and antiaflatoxigenic properties of some essential oil constituents. Lett. Appl. Microbiol., 19:110-113, 1994.

14. Middleton, K.R.; Seal, D. Sugar as an aid to wound healing. Pharmaceutical J., 235:757-758,1985.

15. Morris, J.A.; Khettry, A.; Seitz, E.W. Antimicrobial activity of aroma chemicals and essential oils. J. Amer. Oil Chemists' Soc., 56:595-603, 1979.

16. Pitt, J.I. Food spoilage by xerophilic fungi. In : "Water Relations of Food”. Ed. by R.B. Duckworth, Academic Press , New York, 1974, p. $270-284$.

17. Seal, D.V.; Middleton, K.R. Healing of cavity wounds with sugar. The Lancet, 338:571-572, 1991.

18. Selwyn, D.; Durodie, J. The antimicrobial activity of sugar against pathogens of wounds and other infections of man. In: Simatos, D.; Multon, J.; Dordrech, (eds). Properties of Water in Foods in relation to Quality and Stability. The Netherlands, Martinus Nijhoff Pub., 1985, p. 293-307.

19. Troller, J.; Christian, J.H.B. Water Activity and Food. Academic Press, New York, 1978, p.28-34.

20. Trouillet, J.L.; Fagon, J.Y.; Domart, Y.; Chastre, J.; Pierre, J.; Gibert, C. Use of granulated sugar in treatment of open mediastinitis after cardiac surgery. The Lancet, ii: 180-184, 1985. 